OPEN ACCESS

Edited by:

Hongbin Liu,

Hong Kong University of Science and Technology, Hong Kong

Reviewed by:

Philip Boyd,

University of Tasmania, Australia Martha Gledhill,

University of Southampton, United Kingdom

*Correspondence:

Nicolas Sanchez

nicolas.sanchezpuerto@gmail.com

Specialty section:

This article was submitted to

Aquatic Microbiology,

a section of the journal

Frontiers in Marine Science

Received: 03 August 2017 Accepted: 21 March 2018 Published: 10 April 2018

Citation:

Sanchez N, Brown EA, Olsen Y, Vadstein O, Iriarte JL, Gonzalez HE and Ardelan MV (2018) Effect of Siderophore on Iron Availability in a Diatom and a Dinoflagellate Species: Contrasting Response in Associated

Bacteria. Front. Mar. Sci. 5:118. doi: 10.3389/fmars.2018.00118

\section{Effect of Siderophore on Iron Availability in a Diatom and a Dinoflagellate Species: Contrasting Response in Associated Bacteria}

\author{
Nicolas Sanchez ${ }^{1 *}$, Eunice A. Brown ${ }^{2}$, Yngvar Olsen ${ }^{2}$, Olav Vadstein ${ }^{3}$, Jose L. Iriarte ${ }^{4,5,6}$, \\ Humberto E. Gonzalez ${ }^{6,7}$ and Murat Van Ardelan ${ }^{1}$ \\ ${ }^{1}$ Department of Chemistry, Norwegian University of Science and Technology, Trondheim, Norway, ${ }^{2}$ Department of Biology, \\ Norwegian University of Science and Technology, Trondheim, Norway, ${ }^{3}$ Department of Biotechnology and Food Science, \\ Norwegian University of Science and Technology, Trondheim, Norway, ${ }^{4}$ Instituto de Acuicultura, Universidad Austral de Chile, \\ Puerto Montt, Chile, ${ }^{5}$ Centro COPAS Sur-Austral, Universidad de Concepción, Concepción, Chile, ${ }^{6}$ Centro de Investigación \\ Dinámica de Ecosistemas Marinos de Altas Latitudes, Universidad Austral de Chile, Valdivia, Chile, ${ }^{7}$ Instituto de Ciencias \\ Marinas y Limnológicas, Universidad Austral de Chile, Valdivia, Chile
}

Organic ligands play a key role controlling trace metal bioavailability in the world's oceans, yet the species-specific requirements determining whether certain iron forms can be metabolized largely remain unclear. Siderophores are considered relevant within the pool of ligands keeping iron soluble. We used desferrioxamine B (DFB) to study the siderophore's effect on cultures of Skeletonema costatum and Alexandrium catenella. The experimental approach used semi-continuous additions of iron(II) and DFB over time, reaching final concentrations of 1 and $10 \mathrm{nM} F e$ and 10-10,000 nM DFB. The negative effect of DFB on growth in S. costatum was evident and sharp until day 9 for treatments above $500 \mathrm{nM}$. Delayed growth occurred at $10,000 \mathrm{nM}$, reaching $\sim 80 \%$ of cell density in Controls under both iron conditions. Alexandrium catenella exhibited a less severe negative effect of DFB on growth, only significant at 10,000 nM, while growth was enhanced at lowest DFB. Total bacterial abundance in diatom and dinoflagellate cultures presented inverse trends. While negatively correlated to DFB in diatom cultures, bacteria showed highest abundances in high DFB treatments in dinoflagellate cultures. Delayed growth exhibited in S. costatum at the highest DFB, indicates that favorable changes for Fe uptake occurred over time, suggesting the involvement of other mechanisms facilitating the diatom cell membrane reduction. Overall, unaffected growth in $A$. catenella suggests that this species can use FeDFB and therefore has the capacity to access strongly complexed Fe sources. Contrasting responses in the bacterial community associated with each species highlight the complexity of these interactions, while suggesting that for $A$. catenella it may represent an advantage for acquiring Fe. These results demonstrated the capacity for different uptake strategies among phytoplankton species of different functional groups and underlines the necessity to broaden the study of iron bioavailability on a species basis, alongside interaction with other microbial components such bacteria, to reflect interactions in natural ecosystems.

Keywords: Skeletonema costatum, Alexandrium catenella, associated bacteria, Fe-siderophore, desferrioxamine B, iron bioavailability, non-axenic culture 


\section{INTRODUCTION}

Iron is one of the most functional transition metals present in the biosphere. It came to play a fundamental role in biological systems due to its high abundance during evolution in the primordial ocean and due to its flexible redox chemistry (Hunter and Boyd, 2007). Fe is an essential element in the metabolism of marine organisms (Raven, 1988) for processes such as photosynthesis, respiration, processing of reactive oxygen species and nutrient acquisition (Shaked and Lis, 2012). Yet, due to low solubility of iron(III) and formation of highly insoluble oxyhydroxides in today's oxygenated waters, dissolved iron $(<0.2$ or $0.45 \mu \mathrm{m})$ is present at extremely low concentrations $(<0.5 \mathrm{nM})$ in surface ocean waters (Johnson et al., 1997). Moreover, more than $99 \%$ of dissolved iron is regarded as being bound to organic ligands (Rue and Bruland, 1995; Van Den Berg, 1995). Consequently, this low Fe concentration contributes to the limitation of primary productivity in a significant portion of the world's oceans (Martin and Gordon, 1988; De Baar, 1990). To overcome the elusiveness of iron, microorganisms have developed strategies to enhance their Fe uptake. Laboratory studies have demonstrated that some aerobic bacteria secrete siderophores as part of a high-affinity iron uptake mechanism (Butler, 2005). These molecules may be considered part of the group of strong iron-binding organic ligands found in seawater. Chemical properties of siderophores such as the conditional stability constants have been shown to be similar to constants measured in natural seawater, as a result of naturally occurring ligands (Macrellis et al., 2001; Hunter and Boyd, 2007). Siderophores appear to be part of this group of chelating agents that are able to solubilize iron hydroxides and maintain it in concentrations high enough for cell growth, thus controlling to an extent microbial iron bioavailability (Boukhalfa and Crumbliss, 2002). These Fe-binding ligands appear to be present in both surface and deep waters of the coastal and open ocean, yet there is not a complete understanding of the contribution of specific groups of siderophores to the dissolved pool of $\mathrm{Fe}$ due to the analytical challenges associated with measuring their low concentrations (Gledhill and Buck, 2012). To date, no eukaryotic phytoplankton have been found to excrete siderophores, while there is still a limited understanding on the effect of these compounds on the Fe bioavailability. For instance, whether differences in bioavailability have effects on the phytoplankton assemblage's composition or rates of primary production (Kustka et al., 2015).

Much of the focus on Fe bioavailability has been on HNLC and oceanic ecosystems, yet iron likely has an equally important regulatory role in coastal waters, even becoming a limiting nutrient at least on a seasonal basis (Hutchins et al., 1998; Bruland et al., 2001; Öztürk and Bizsel, 2003). Though siderophores are believed to be more abundant in oceanic environments than coastal environments, the presence of hydroxymate type siderophores has been reported for coastal waters (Mawji et al., 2008; Velasquez et al., 2011; Boiteau et al., 2016), suggesting a potential role for these types of ligands in these environments. Moreover, Fe requirements of neritic phytoplankton are not only comparatively higher relative to oceanic phytoplankton, but also differ substantially among species, so that iron fluctuations within metal-replete systems should strongly influence the composition and distribution of phytoplankton assemblages (Wells, 1999). Despite this, much of the research for coastal environments to date has been centered on few diatom species (Hutchins D. et al., 1999), with greater focus on the genus Thalassiosira (Sunda and Huntsman, 1995) and less attention on species such as Phaeodactylum tricornutum (Soria-Dengg and Horstmann, 1995; Soria-Dengg et al., 2001). Less attention has been paid to other phytoplankton groups that have been found capable of accessing iron sources other than solely the dissolved pool. For instance, in phytoflagellates Fe acquisition can occur through mixotrophy by colloid ingestion (Nodwell and Price, 2001). Dinoflagellates, also with mixotrophic capabilities, play a relevant role from both the ecological perspective by structuring phytoplankton assemblages and from the ecosystems services perspective by promotion of harmful algal blooms (HABs) (Jeong et al., 2010). Early studies reported on the relation of episodic pulses of iron from water runoff, land drainage or sediment resuspension to the initiation of red tide dinoflagellate blooms (Ingle and Martin, 1971; Glover, 1978). With respect to dinoflagellates and siderophores, claims of isolation of a siderophore from eukaryotic origin have been made for Prorocentrum minimum (Trick C. G. et al., 1983). However, evidence was not conclusive due to either lack of clean techniques at the time, or the possibility of bacterial contamination and production of siderophores (Sunda, 2001). More recent evidence has suggested that coastal dinoflagellates may be more susceptible to the effects of reduced iron availability than other neritic phytoplankton (Doucette and Harrison, 1990, 1991). More recently, several dinoflagellate species, previously defined as solely autotrophic (such as the red tide dinoflagellate Alexandrium catenella) have been later recognized as mixotrophic, hence changing the perspective of their ecologic role. Dinoflagellates capable of ingesting bacteria may a have direct impact on iron availability by predating on bacteria or may contribute indirectly by predating on protists which in turn prey upon bacteria (Bockstahler and Coats, 1993; Jeong et al., 2005, 2007).

Given the high phytoplankton diversity and the different trophic modes, competition between eukaryotes together with prokaryotes for organically bound iron strongly depends on the chemical nature of Fe complexes, with ultimate consequences for ecological niche separation and plankton community sizestructure (Hutchins D. A. et al., 1999). Regardless of recent advances, the nature of the specific relationship between certain iron species being bioavailable to certain groups/species of phytoplankton is still not fully elucidated. Marine bacteria has been shown to release hydroxamate siderophores such as desferrioxamine (McCormack et al., 2003; Gledhill et al., 2004; Mawji et al., 2008). Based on this finding, desferrioxamine has become a common siderophore to be used in marine laboratory experiments. Results with desferrioxamine $B$ have shown a wide variety of responses with regard to the bioavailability of this siderophore-complex (Hutchins D. A. et al., 1999; Hassler and Schoemann, 2009). Even within studies of the same species different results were obtained, which demonstrates that the 
nutritional status of cells (Maldonado and Price, 2001), and the experimental approach (Shaked and Lis, 2012) can affect the interpretation of the bioavailability of Fe complexes.

Here we aimed to study the bioavailability of iron for different species belonging to separate functional groups of phytoplankton from the coastal environment under experimental conditions. We used a dynamic approach which uses moderated addition of iron and the organic ligand desferrioxamine B (DFB). Under controlled conditions the diatom Skeletonema costatum and the dinoflagellate Alexandrium catenella, were grown under semicontinuous additions of iron and a concentration gradient of the siderophore to seek its effects on the overall physiology of the algae. Interactions with the associated bacteria are discussed with respect to the potential role for nutrient acquisition in different functional groups of phytoplankton.

\section{MATERIALS AND METHODS Water Collection and Conditioning}

Seawater collected for the cultures was obtained from the laboratory facilities of the Trondheim Biological Station $\left(63^{\circ} \mathrm{N}\right)$, Trondheim Norway. Water intake is located at a depth of $\sim 80 \mathrm{~m}$ with a bottom depth of $\sim 100 \mathrm{~m}$. Water was collected during November 2014 when concentrations of total dissolvable iron in Trondheim's fjord $(10-50 \mathrm{~m})$ range between 5 and $12 \mathrm{nM}$ (Öztürk et al., 2002). A volume of 50 liters was collected in five $10 \mathrm{~L}$ acid-washed PE Nalgene bottles. All water was filtered through acid washed filters $(0.45+0.2 \mu \mathrm{m}$ Sartorius Sartobran 300) and autoclaved. To condition the seawater to low iron concentrations, an ion exchange resin (Chelex-100 - Bio-Rad Laboratories) was used to complex most kinetically labile $\mathrm{Fe}$ forms. For each $10 \mathrm{~L}$ bottle, $2 \mathrm{~mL}$ of Chelex-100 slurry $(\sim 0.4$ gr dry weight) was added. Bottles were then put on a shaker for $24 \mathrm{~h}$ at room temperature. Afterwards, all water was filtered through silicon tubing using a peristaltic pump, passing all content through an acid-washed Poly-prep Chromatography column with a built-in polyethylene frit (pore size 100-300 $\mu \mathrm{m}$ size; Bio-Rad Laboratories). An extra $0.5 \mathrm{~mL}$ of Chelex slurry was added to the filters, and the water was pumped at a rate of $3 \mathrm{~mL} \min ^{-1}$. To determine the background iron concentration, triplicate samples were collected after filtration. Extraction was carried out using a batch technique by adding $0.2 \mathrm{~mL}$ of ion exchange resin Toyopearl AF-Chelate $650 \mathrm{M}$ (Tosoh). After $12 \mathrm{~h}$ on a shaker $(\sim 80 \mathrm{rpm})$, samples were extracted in a 2-step acidifying process (Ardelan et al., 2010). Initial background $\mathrm{Fe}$ concentrations were determined as $0.76 \pm 0.4$ and $2.59 \pm 0.5 \mathrm{nM}$ for the dissolved labile iron (DFe) and the total dissolvable iron (TDFe) respectively. The former fraction corresponds to the dissolved Fe complexed by the resin at seawater $\mathrm{pH}$, while the latter corresponds to the Fe fraction extracted after acidification of the sample to $\mathrm{pH} \sim 1.7$ for $\sim 3$ months and then brought back to $\mathrm{pH} \sim 6$ for extraction.

\section{Cultures Setup}

Cultures were kept in a temperature- controlled room maintained between 14.5 and $15^{\circ} \mathrm{C}$ and $40-60 \%$ humidity. The light regime was a $24 \mathrm{~h}$ light cycle with fluorescent lighting with a mean luminous intensity of $80-90 \mu \mathrm{mol} \mathrm{m} \mathrm{m}^{-2} \mathrm{~s}^{-1}$. The organisms used in this study were obtained from the Norsk Institutt for vannforskning -NIVA (S. costatum: NIVA-BAC 36 strain culture) and from Scandinavian culture collection of Algae and Protozoa (SCAAP) from the University of Copenhagen (A. catenella K-1490 strain). The strains were maintained in a normal f/2 medium (Guillard and Ryther, 1962) and L1 (Guillard and Hargraves, 1993) medium for the diatom and dinoflagellate respectively. Both the diatom and dinoflagellate strains came from non-axenic cultures. Given that axenic dinoflagellate cultures often cannot be established, and even when they can, they require the addition of vitamins and artificial metal complexes for satisfactory viability (Green et al., 2004), the establishment of a sterile medium allowed only for the presence of the native bacterial community from each strain. Due to the intrinsic lower specific growth rate (Tang, 1996), the cell density reached for $A$. catenella was lower than expected at the start of the experiment. The growth exhibited resulted in a delayed response and for this reason the length of the experimental time employed with this species was longer than that in the diatom cultures.

The experiments were conducted in an EDTA/metal ion buffered seawater medium modified from the artificial algal culture medium Aquil (Price et al., 1989). All macronutrients (nitrogen, phosphorus, and silicon) were prepared and kept as independent stocks, then individually passed through a column containing Chelex-100. Trace metal enrichment was done based on a doubled concentration of EDTA $(10 \mu \mathrm{M})$, adjusting the total concentration of each metal to achieve the same free ion concentration of $\mathrm{pFe}$ (18.18), $\mathrm{pCu}$ (13.79), pMn (8.27), pZn (10.88), and pCo (10.88) (Price et al., 1989). For the growth of dinoflagellates, selenium, nickel, vanadium, and chromium were also added. The experimental medium contained the minimum FeEDTA recommended for iron studies (Morel et al., 1979), in order to guarantee sustained growth for the duration of the experiment. In this way, the Control is determined as the growth achieved based on (a) the background DFe in the medium after chelex conditioning, (b) the dissociated Fe from the EDTA, and (c) the extra Fe(II) addition (see below). To adapt the microalgae to the growth conditions required for the experiments, $1 \mathrm{~mL}$ aliquots of the original $\mathrm{f} / 2$ and L1 media were transferred to a low iron growth medium. Following growth in the low iron medium for two consecutive batch cultures, an aliquot was transferred to a third low iron medium. Once this culture reached the late exponential phase, a $1 \mathrm{~mL}$ aliquot was transferred to be used in the experiment. This was done in order to minimize all possible contamination from the original $\mathrm{f} / 2$ and L1 media and to allow the species to adapt to low iron conditions.

\section{Experimental Setup}

Eighty-four $500 \mathrm{~mL}$ acid-washed polycarbonate (PC) bottles (VWR sterile tissue culture flask) were used. Half of the bottles were used with $S$. costatum and half with A. catenella. For each species, two combinations (total four combinations) were arranged, each consisting of one iron condition (1 or $10 \mathrm{nM})$ and six different siderophore treatments (10, 50, 100, 500, 2,500 , and $10,000 \mathrm{nM}$ ) plus a control. Each treatment within the 
experimental setup was run in triplicate with 21 bottles per each combination (Table 1). Each Control had the corresponding $\mathrm{Fe}$ addition but no siderophore addition. All macro- and micronutrients required in the culture were added at the start of the experiment.

\section{Iron and Siderophore Addition}

The two iron conditions were achieved by the addition of ammonium iron(II) sulfate hexahydrate $\left(\left(\mathrm{NH}_{4}\right)_{2} \mathrm{Fe}\left(\mathrm{SO}_{4}\right)_{2}\right.$ *6H2O). Fe(II) is considered the most readily bioavailable form of iron, and was added in order to stimulate potential uptake of $\mathrm{Fe}(\mathrm{II})$ rather than $\mathrm{Fe}(\mathrm{III})$ already present. The siderophore treatments consisted of the addition of the uncomplexed (apoform) siderophore desferrioxamine Mesylate (DFB) salt powder (Sigma). Desferrioxamine $\mathrm{B}$ is a hexadentate organic ligand with hydroxamate functionalities and linear acyclic architecture (Albrecht-Gary et al., 1998). It is a strong Fe-complexing agent, capable of forming photostable complexes (Finden et al., 1984; Barbeau et al., 2003) and its conditional stability constant with respect to total inorganic iron (Fe') is $10^{16,5} \mathrm{M}^{-1}$ in seawater (Hudson et al., 1992) Two stock solutions (80 and $400 \mathrm{nM}$ ) were made for Fe and two stock solutions (11.6 and $1160 \mu \mathrm{M})$ of DFB for the six different treatments. To achieve the target concentrations, small amounts of Fe and DFB were added every third day until the desired conditions were met. For 1 and $10 \mathrm{nM} \mathrm{Fe}(\mathrm{II})$ conditions (hereafter 1 and $10 \mathrm{nM} \mathrm{Fe}$ ), a total of five additions of 0.2 and $2 \mathrm{nM}$ Fe respectively were employed. Likewise, five partial DFB additions were performed until reaching the final concentration in each of the six DFB treatments (Table 2). The partial additions for $\mathrm{Fe}$ and $\mathrm{DFB}$ coincided and were performed immediately after sample collection. In $S$. costatum cultures, partial addition ended at day 12 of the experiment, whereas in A. catenella cultures, addition at day 12 was skipped, with a final addition on day 15 .

HPLC-ESI-MS was used to detect possible degradation of the apo- siderophore in a separate test after the conclusion of the experiment in a similar culture medium without algae presence. Analysis for DFB detection was based on Mawji et al. (2008). Non-targeted LC-MSE (MS/MS) analysis was performed on a Waters $^{\text {TM }}$ Acquity uHPLC Synapt-G2S Q-TOF system with ESI positive mode. Extraction efficiency ( $26 \%)$ was similar to other reports (McCormack et al., 2003).Identification was by fragmentation data from collision induced dissociation (Velasquez et al., 2011).

\section{Samples Collection and Analysis}

All sample collection to determine DFe as well as the manipulation of the experimental bottles during addition and sampling was performed under a Class-100 laminar flow hood (AirClean-600 PCR Workstation) to minimize possible contamination. Samples were analyzed by High Resolution Inductive Coupled Plasma Mass Spectrometry (HR-ICP-MS) Element 2 (Thermo-Finnigan) with a PFA-Schott type spray chamber and nebulizer. The detection limit used here is three times the standard deviation of the measured method blank values $(0.08 \pm 0.02 \mathrm{nmol} ; n=10)$. Method accuracy for total and dissolved chelex labile samples was determined by extraction of certified seawater reference material for trace metal NASS-6 (National Research Council of Canada), with a mass concentration for iron of $0.495 \pm 0.046 \mu \mathrm{g} . \mathrm{L}^{-1}(8.8 \mathrm{nM})$. The recovery was on average $87 \%(n=16)$.

Before every Fe and DFB addition, samples $(\sim 10 \mathrm{~mL})$ were collected to measure: $\mathrm{pH}$, photosynthetic efficiency (Fv/Fm), in-vivo fluorescence (FSU), cell and total bacterial abundance. At the end of the experiment, samples were collected for $\mathrm{DFe}$ (see above). To estimate the Fv/Fm, an aliquot of the sample was transferred into a cuvette (under dim light) and measured on a field portable device AquaPen -C 100, (Photon systems instruments). For the FSU, a Turner designs (Trilogy) fluorometer was used. For the diatom and dinoflagellate abundance, aliquot counts were performed in a Bürker-Türk chamber under a microscope. For the former, the number of cells in random chamber transects (40x) was counted, while for the latter the entire chamber $(20 \mathrm{x})$ was covered. The initial abundances for $S$. costatum and A. catenella cultures were of $\sim 8,000$ and $\sim 200$ cells $\mathrm{mL}^{-1}$, respectively. The growth rate, estimated in doublings per day $\left(\mathrm{d}^{-1}\right)$, was calculated from the linear regression from the $\mathrm{Ln}$ of the cell abundance (specific growth rate; $\mu$ ) divided by $\operatorname{Ln} 2$, vs. time for each treatment (Guillard, 1973). Given the lack of a distinctive exponential phase in A. catenella cultures, the estimation of this variable resulted in larger standard deviations in the average values.

For total bacterial abundance, $1.5 \mathrm{~mL}$ samples from selected DFB treatments (Control, 10, 100, and 10,000 nM) were fixed with Glutaraldehyde (25\%), frozen in liquid nitrogen and then stored $\left(-20^{\circ} \mathrm{C}\right)$ until analysis by flow cytometry (Marie et al., 1997). The samples were diluted $1: 10$ or $1: 100$ with $0.1 \mathrm{x}$ TEbuffer, depending on cell density. The bacterial cells were stained with $10 \mu$ 1:50 diluted SYBR Green I Nucleic Acid Gel Stain (10.000X in DMSO; Molecular Probes) per $1 \mathrm{~mL}$ of diluted sample, and incubated in the dark for $15 \mathrm{~min}$ before analysis. Flow cytometry measurements were performed on a BD Accuri C6 Flow Cytometer (BD Bioscience, San Jose) and blue laser (excitation $488 \mathrm{~nm}$ ). All samples were analyzed with the same instrumental setting: medium flow rate $\left(34.5 \mu \mathrm{L} \min ^{-1}\right)$, FL1 threshold of 2,000 and sample collection for $3 \mathrm{~min}$. Medium flow

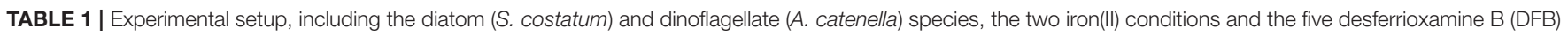
treatments with the respective final concentrations $(\mathrm{nM})$ reached in the experiment performed.

\begin{tabular}{|c|c|c|c|c|c|c|c|c|c|c|c|c|c|c|c|}
\hline Species & $\mathrm{Fe}(\mathrm{II})(\mathrm{nM})$ & & & & 1 & & & & & & & 10 & & & \\
\hline S. costatum & DFB (nM) & Control & 10 & 50 & 100 & 500 & 2,500 & 10,000 & Control & 10 & 50 & 100 & 500 & 2,500 & 10,000 \\
\hline A. catenella & & Control & 10 & 50 & 100 & 500 & 2,500 & 10,000 & Control & 10 & 50 & 100 & 500 & 2,500 & 10,000 \\
\hline
\end{tabular}


TABLE 2 | Background dissolved labile iron (DFe) (nM) and FeEDTA complex (nM) present in the culture medium (Left). Supply ratio of desferrioxamine B (DFB) to iron(II) ratio added every other day for the $1 \mathrm{nM}$ (Center) and $10 \mathrm{nM}$ (Right) Fe(II) conditions until target concentrations were reached for each treatment in the experiment performed with S. costatum and A. catenella.

\begin{tabular}{|c|c|c|c|c|c|c|c|c|}
\hline DFe bg (nM) & FeEDTA (nM) & Treatment & $\mathrm{Fe}(\mathrm{II})\left(\mathrm{nM} \mathrm{d} \mathrm{d}^{-1}\right)$ & $\mathrm{DFB}\left(\mathrm{nM} \mathrm{d} \mathrm{d}^{-1}\right)$ & [DFB]:[Fe] & $\mathrm{Fe}(\mathrm{II})\left(\mathrm{nM} \mathrm{d}^{-1}\right)$ & $\mathrm{DFB}\left(\mathrm{nM} \mathrm{d} \mathrm{d}^{-1}\right)$ & [DFB]:[Fe] \\
\hline 0.7 & 40 & Control & 0.2 & & & 2 & & \\
\hline 0.7 & 40 & 10 & 0.2 & 2 & 10 & 2 & 2 & 1 \\
\hline 0.7 & 40 & 100 & 0.2 & 20 & 100 & 2 & 20 & 10 \\
\hline 0.7 & 40 & 500 & 0.2 & 100 & 500 & 2 & 100 & 50 \\
\hline
\end{tabular}

rate was used to increase accuracy when counting bacterial cells. Bacteria present in the cultures had initial abundances of 2,039 \pm 529 and $1,597 \pm 155$ cell $\mu \mathrm{L}^{-1}$ in S. costatum and A. catenella respectively.

\section{Data Analysis}

The analysis of data was performed with the statistical Software SYSTAT Sigma Plot 13. Parametric tests were carried out to determine homoscedasticity of the data. For analysis between different treatments within the same $\mathrm{Fe}(\mathrm{II})$ condition, analysis of variance (one-way ANOVA) and Post-hoc Tuckey HSD Test for differences were performed. For comparisons of response variables at different $\mathrm{Fe}(\mathrm{II})$ conditions for the same species, paired $T$-tests were performed. The level of significance was set to 0.05 . When data was not suitable for parametric tests, ANOVA on ranks were performed.

\section{RESULTS}

The effect of the DFB gradient on the growth and overall algal physiology was evident in both the diatom and the dinoflagellate cultures, although more attenuated in the latter (Figures 1, 2). The effect of Fe(II) addition was less consistent showing significant differences only in specific treatments and in some of the variables measured during the experiment in both S. costatum and A. catenella cultures (Table 3). Generally, DFB treatments at $10 \mathrm{nM}$ Fe showed a weaker or delayed response as compared with the $1 \mathrm{nM}$ Fe treatments. This effect was seen in both species. Given the trends, the results described below refer to both 1 and $10 \mathrm{nM}$ Fe unless otherwise is stated.

\section{Skeletonema costatum Response}

The concentration gradient of DFB was negatively correlated with the growth of the diatom. Cultures with the lower siderophore concentration exhibited a shorter lag phase similar to the Control. That is, 10, 50, and $100 \mathrm{nM} \mathrm{DFB}$ treatments exhibited a lesser effect and together with the Control, reached maximum densities between day 9 and 10. This is represented consistently in all other variables measured: $\mathrm{pH}$, in-vivo fluorescence and photosynthetic efficiency. For the 500, 2,500, and $10,000 \mathrm{nM}$ treatments, the negative effect of the siderophore on the diatom was evident as little or no growth was observed by day 7. Near half of the exponential phase in the Control, growth was observed at high DFB treatments with increasing cell densities. By day 9-10, growth was evident with the $500 \mathrm{nM}$ treatments reaching half of the density in the Controls. At the end of exponential phase in the Controls (day 9-10), cell abundances ranged between $907 \times 10^{3}$ and $883 \times 10^{3}$ cells $\mathrm{mL}^{-1}$ while abundances at $500 \mathrm{nM}$ represented $\sim 20 \%$ during the same period. By day 13, treatments with higher siderophore addition managed to reach cell densities $60-84 \%$ of the maximum reached in the Controls. Regardless of the longer lag phase in higher DFB treatments $(2,500$ and $10,000 \mathrm{nM})$, by the end of the experiment the cell abundance in these treatments reached similar levels to that of 10 and $50 \mathrm{nM}$ reached earlier.

By day 9, the effect of Fe(II) concentration on the monitored variables at $1 \mathrm{nM}$ Fe showed overall significantly higher values in the treatments than at $10 \mathrm{nM}$ Fe, except at $10 \mathrm{nM}$ DFB and Control (Table 3). At $10 \mathrm{nM} \mathrm{Fe}$, the values of the monitored variables continued to increase after day 9 , therefore suggesting a faster response of the diatom at lower Fe. The growth rate showed the same trend between treatments at 1 and $10 \mathrm{nM} \mathrm{Fe}$ (Figure 3A). With the exception of the $10 \mathrm{nM} \mathrm{DFB}$, the growth rate showed a decreasing trend in treatments at both 1 and $10 \mathrm{nM}$ Fe. The 10,000 DFB treatments showed the lowest growth rates with significant differences (1-way ANOVA; $d f=6$; Tukey HSD) compared to the respective Controls at 1 and $10 \mathrm{nM} \mathrm{Fe}$. A further paired comparison between $\mathrm{Fe}$ conditions showed the growth rate in the Control at $10 \mathrm{nM}$ Fe to be significantly higher. It was the only treatment in the $10 \mathrm{nM}$ Fe group having a higher growth rate than those at $1 \mathrm{nM}$ Fe. Although average growth rates at the same siderophore concentration were higher at $1 \mathrm{nM} \mathrm{Fe}$, significant differences were only found at 10,000 nM DFB (Table 3). The $10 \mathrm{nM}$ DFB treatment at $1 \mathrm{nM}$ Fe had a significantly higher growth rate (1-way ANOVA; $d f=6$; Tukey HSD) than the Control, and were the only results that suggest DFB addition has an enhancing effect on the growth.

\section{Alexandrium catenella Response}

The dinoflagellate exhibited overall slower growth regardless of the siderophore concentration. This resulted in the absence of a distinct lag phase, with a rather prolonged and smooth exponential growth pattern over the extended period of the culture. The effect of the DFB gradient on the monitored variables only showed noticeable differences between treatments 


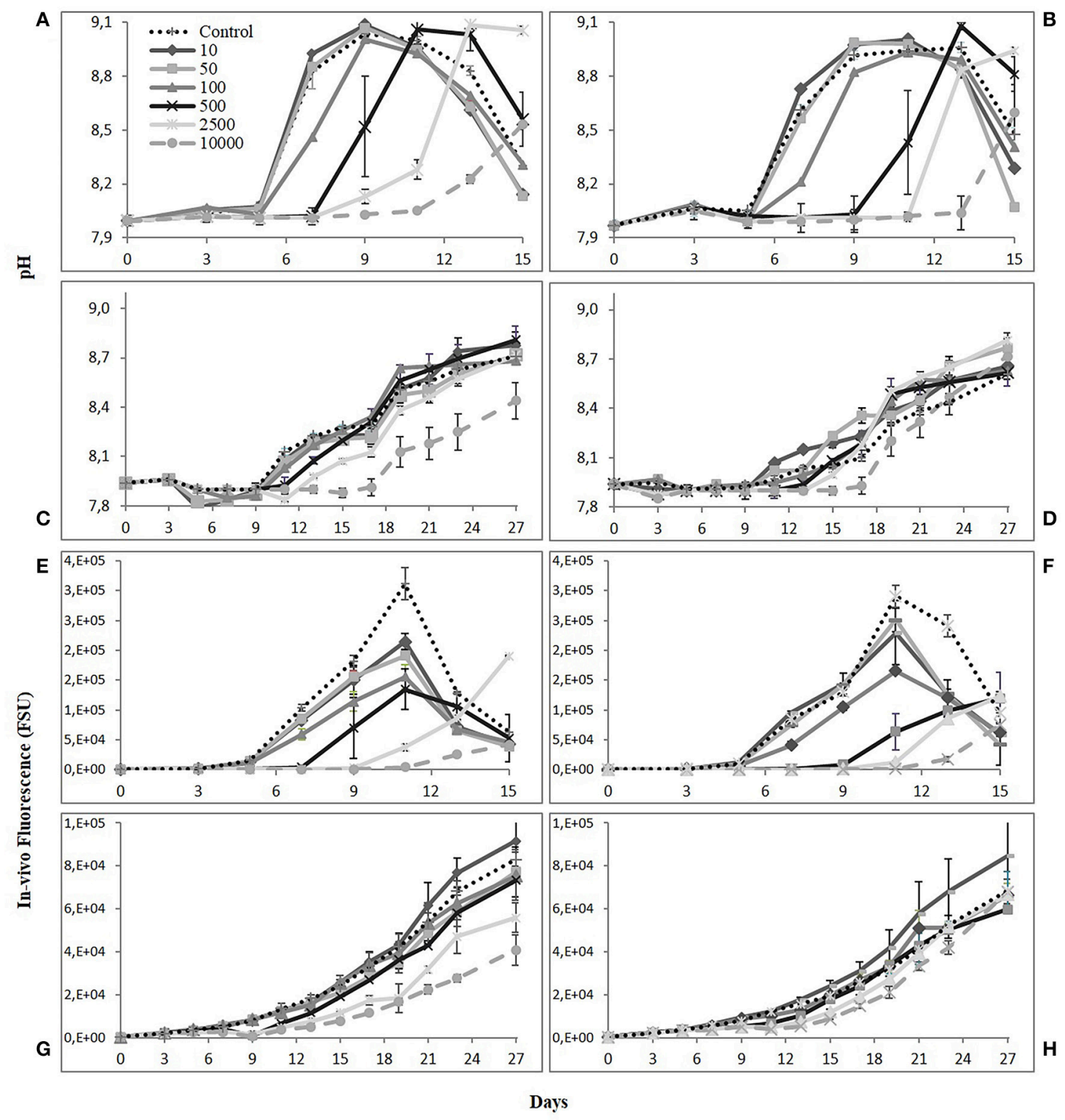

FIGURE 1 | pH and In-vivo fluorescence (FSU) for Skeletonema costatum (A,B,E,F) and Alexandrium catenella cultures (C,D,G,H) over time. Left graphs (1 nM Fe) and right graphs (10 nM Fe). Error bars: standard deviation $(n=3)$.

from day 8 to 10 onwards. The only treatment with a positive effect on growth compared to the Control was the $10 \mathrm{nM} \mathrm{DFB}$, as shown by cell density and FSU. This was consistent in both 1 and $10 \mathrm{nM} \mathrm{Fe}$, only with an average higher cell abundance in the latter. Final densities in the $10 \mathrm{nM}$ DFB treatment showed positive effects with values 17 and $38 \%$ higher than the Controls for 1 and $10 \mathrm{nM}$ Fe respectively. In the FSU, a distinctive drop at day 9 for the 500,2,500, and 10,000 nM DFB treatments at $1 \mathrm{nM} \mathrm{Fe}$ was observed. The same feature was present at $10 \mathrm{nM} \mathrm{Fe}$, but at day 11 and for the 2,500 and 10,000 nM DFB treatments. The Fv/Fm data followed the same pattern of the other monitored variables measured, but the differences between treatments were lower than for $\mathrm{pH}$ or cell abundance. By day 7 after reaching average values of 0.4 and 0.6 in the high and low siderophore treatments respectively, the Fv/Fm remained constant throughout the experiment.

Comparisons between monitored variables at the same siderophore concentration at the end of the experiment, showed that $\mathrm{Fe}$ (II) addition had significant differences in the Control and lowest siderophore treatment, with higher $\mathrm{pH}$ and cell density at $10 \mathrm{nM}$ Fe. Similarly, at 10,000 nM DFB pH and FSU were significantly higher at $10 \mathrm{nM} F$, whereas cell abundance at $2,500 \mathrm{nM}$ was the only significantly higher value at $1 \mathrm{nM}$ $\mathrm{Fe}$ (Table 3). The growth rate for $A$. catenella ranged from 


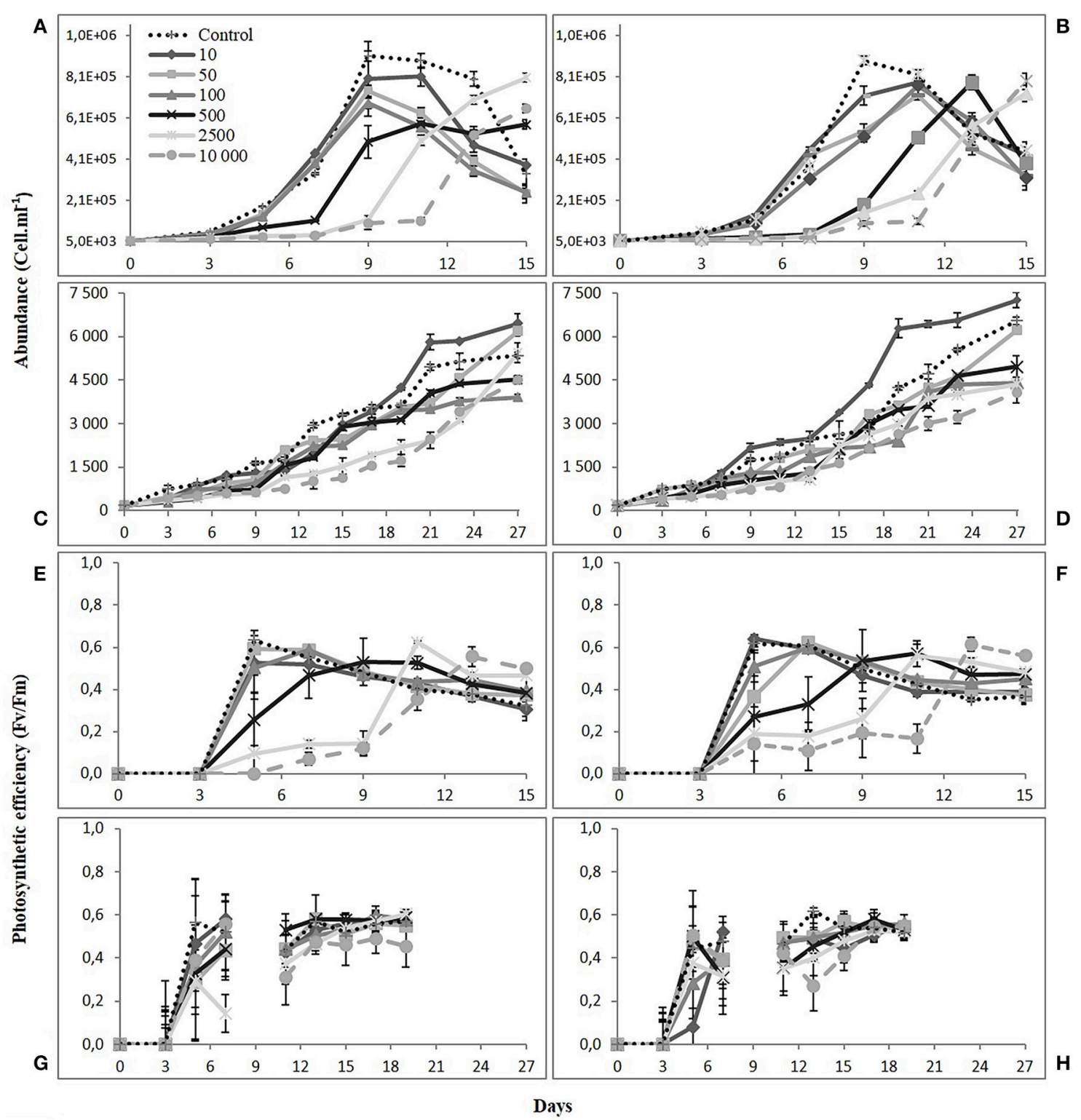

FIGURE 2 | Cell abundance (cell $\mathrm{mL}^{-1}$ ) and photosynthetic efficiency (Fv/Fm) for Skeletonema costatum (A,B,E,F) and Alexandrium catenella. (C,D,G,H) over time. Left graphs ( $1 \mathrm{nM} \mathrm{Fe})$ and right graphs (10 nM Fe). Error bars: standard deviation $(n=3)$.

0.13 to $0.19 \mathrm{~d}^{-1}$ following no distinct trend in time, showing no significant effect of the DFB gradient at any of the $\mathrm{Fe}(\mathrm{II})$ conditions (Figure 3B). Except from a growth rate value significantly higher at $500 \mathrm{nM}$ DFB than Control at $1 \mathrm{nM} \mathrm{Fe}$, there were no other significant differences (ANOVA on Ranks, $d f=6$ ) between DFB treatments and Controls. A further paired comparison between Fe conditions also showed no significant differences at any DFB concentration (Table 3).

\section{Bacterial Community Response}

Figure 4 shows the trend over three points in time for the total bacterial abundance for both iron conditions in the diatom and dinoflagellate cultures. Bacteria present in S. costatum cultures exhibited a similar pattern over time to that of the diatom abundance both at 1 and $10 \mathrm{nM} \mathrm{Fe}$. That is, the effect on the abundance of the associated bacteria was also negatively correlated to the DFB concentration, with the 10,000 nM DFB treatment showing significantly lower (ANOVA on Ranks; $d f=3$ ) numbers than the Control at the end of the experiment. The pattern was the same at the $10 \mathrm{nM}$ Fe condition only with a final lower bacterial density in the Control compared to that at $1 \mathrm{nM}$ Fe. On the contrary, over time $A$. catenella bacterial abundance presented the inverse pattern seen in S. costatum cultures. Compared to the Controls, bacterial abundance increased over time both at 1 and $10 \mathrm{nM}$ $\mathrm{Fe}$, positively correlated to DFB concentration. At the end of 


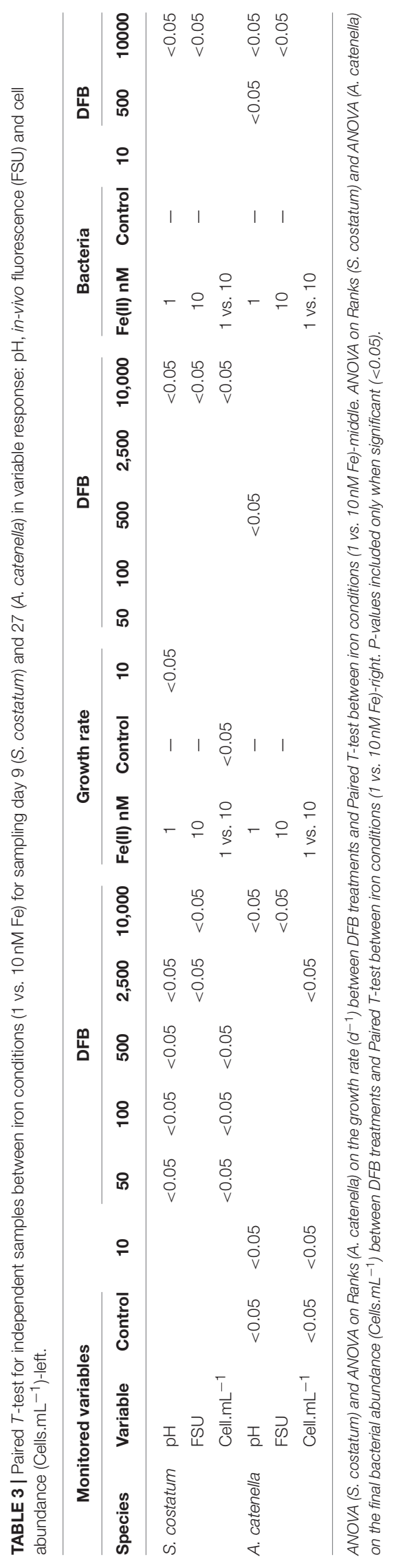

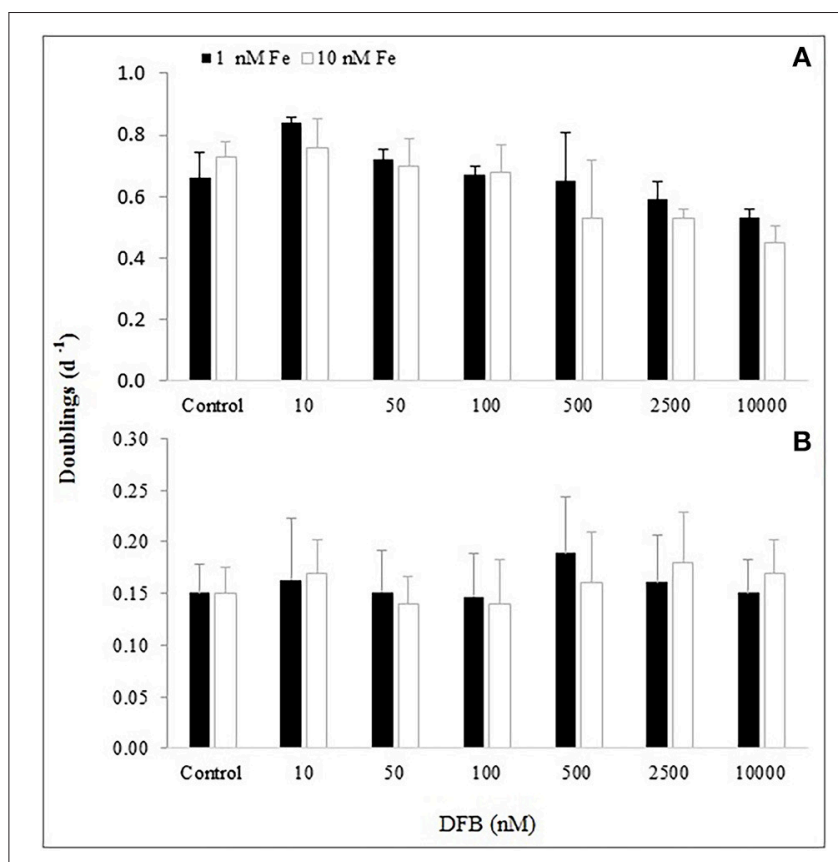

FIGURE 3 | Growth rate (doublings $\mathrm{d}^{-1}$ ) for (A) the diatom Skeletonema costatum and $\mathbf{( B )}$ the dinoflagellate Alexandrium catenella, based on cell density measured at exponential phase $(L n)$ for each treatment performed with desferrioxamine $B$ (DFB).

the experiment, the bacterial abundance at $10,000 \mathrm{nM}$ DFB was significantly higher (1-way ANOVA; $d f=3$; Tukey HSD), than both Controls ( 1 and $10 \mathrm{nM} \mathrm{Fe}$ ). The lowest densities at $10 \mathrm{nM}$ DFB were not significantly different from the Controls. The Fe(II) concentration showed no effect on bacterial abundance in any of the DFB treatments (Table 3). The abundances reached in Controls of the dinoflagellate cultures were 50 and 25\% lower at 1 and $10 \mathrm{nM}$ Fe respectively, compared to those reached in Controls in the diatom cultures.

\section{Final Dissolved Labile Iron in Cultures}

Final DFe measured in the three treatments plus the Control (Figure 5), showed no correlation relative to the DFB concentration in neither the diatom nor in the dinoflagellate cultures. At both 1 and $10 \mathrm{nM}$ Fe in S. costatum cultures, the $10,000 \mathrm{nM}$ DFB treatment had the lowest concentrations, but only significantly different at $1 \mathrm{nM}$ Fe (1-way ANOVA; $d f=3$; Tukey HSD). At $500 \mathrm{nM}$ DFB, DFe was significantly higher (1-way ANOVA; $d f=3$; Tukey HSD) than Control in both Fe conditions. In Alexandrium catenella cultures, final DFe had a similar distribution but all values in treatments at 1 and $10 \mathrm{nM}$ Fe presented significantly higher values than the Control (1-way ANOVA; $d f=3$; Tukey HSD). Final DFe values in A. catenella cultures in every treatment in both $\mathrm{Fe}$ (II) conditions were higher than the corresponding treatment in S. costatum cultures. Also, in A. catenella cultures DFe values at 500 and $10,000 \mathrm{nM}$ at $1 \mathrm{nM}$ $\mathrm{Fe}$, and in all treatments at $10 \mathrm{nM}$ Fe were higher than values measured for initial DFe and TDFe. The latter is indicative of possible changes that occurred over time in the Fe speciation, 


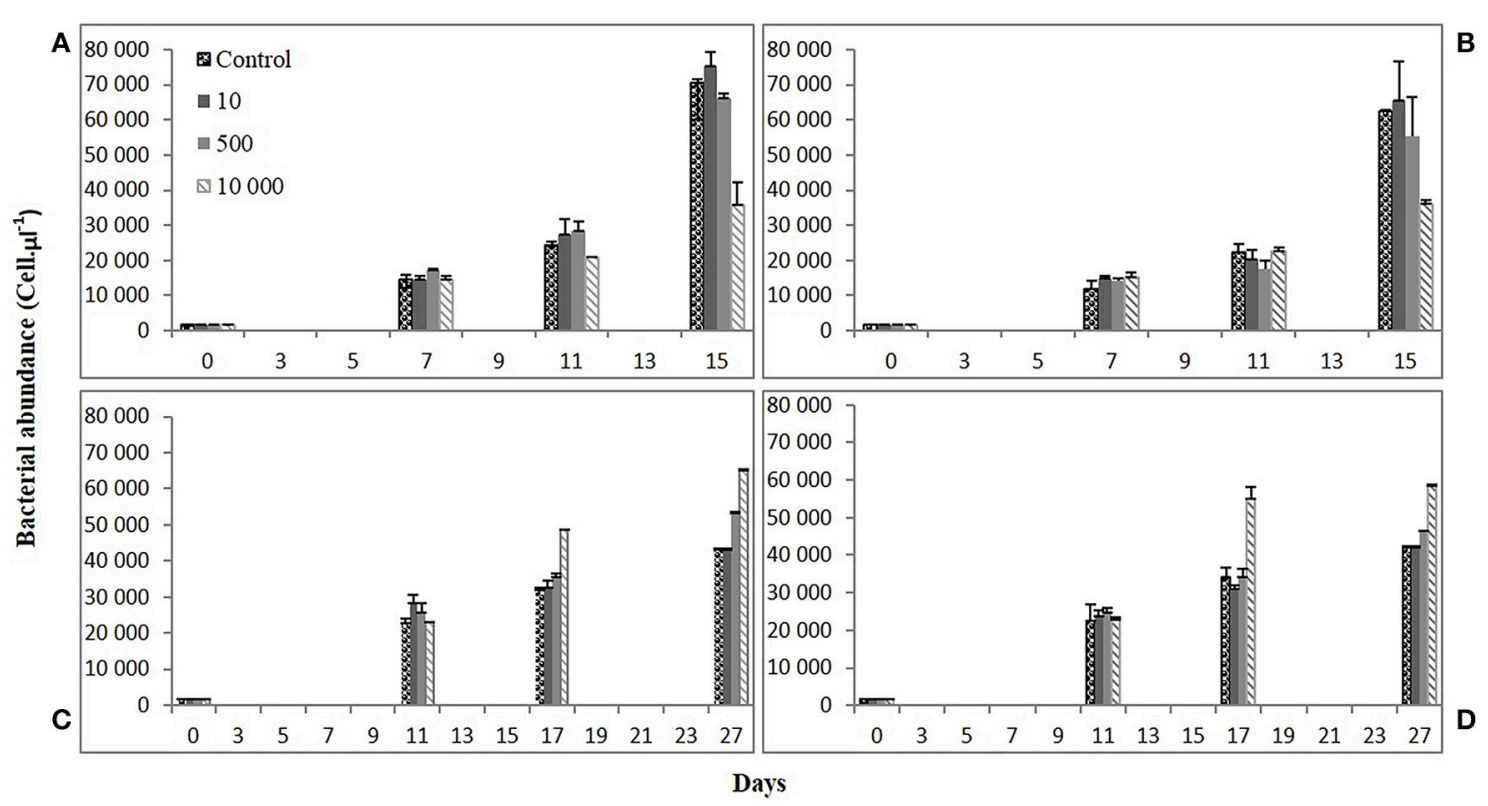

FIGURE 4 | Bacterial abundance (cell $\mu \mathrm{L}^{-1}$ ) along time for Skeletonema costatum $\mathbf{( A , B )}$ and Alexandrium catenella (C,D) cultures in four of the desferrioxamine (B) (DFB) treatments selected (Control, 10, 500, 10,000 nM). Error bars: standard deviation $(n=3)$.

allowing for the extraction of a larger labile Fe fraction (based on Chelex resin) compared to the beginning of the experiment.

\section{DISCUSSION}

\section{Iron Supply and Under Low and High DFB}

Natural seawater was used to reduce the levels of dissolved labile iron and therefore, the already present organic matter must be acknowledged as potential source of available metal binding ligands for iron. However, the TDFe measured after water conditioning indicated that only a relatively low concentration source of iron was strongly complexed. Moreover, the high conditional stability constant of desferrioxamine with respect to total $\mathrm{Fe}^{\prime}\left(\mathrm{K}^{\prime}=10^{13} \mathrm{M}^{-1}\right)$, makes it a stronger Fe complexing agent than organic chelators naturally present in seawater (Rue and Bruland, 1995). Furthermore, collection of the water during the late autumn ensured the smallest amount possible of phytoplankton derived organic matter. Regarding the concentration of artificial chelators, the presence of $10 \mu \mathrm{M}$ EDTA in the basal Aquil medium ensured an excess concentration relative to DFB in all treatments except in the highest one. However, DFB is known to react faster with $\mathrm{Fe}(\mathrm{OH}) \mathrm{EDTA}$ than with FeEDTA at seawater pH (Tufano and Raymond, 1981), so the DFB kinetics impede an efficient rate of extraction of Fe by EDTA. Also, the high affinity of EDTA for $\mathrm{Ca}^{2++}$ and $\mathrm{Mg}^{2++}$ (Hudson and Morel, 1990) reduce the apparent equilibrium concentration of reactive EDTA. In this way, use of an ample gradient of the siderophore offset any probable effect of unaccounted iron and ligands present in the seawater after conditioning.

The addition every third day of the apo-siderophore instead of a one-time addition of an already pre-equilibrated Fe-complex

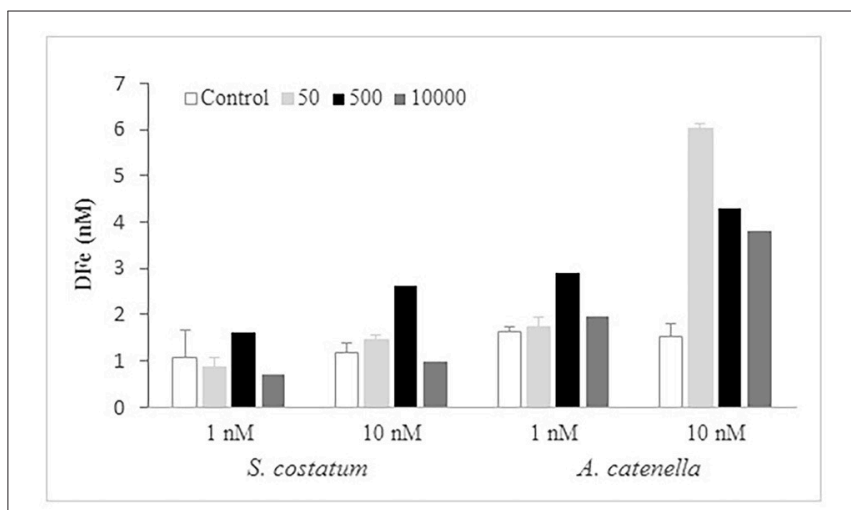

FIGURE 5 | Dissolved labile iron (DFe) concentration (nM) measured at the final day for four of the desferrioxamine B (DFB) treatments (Control, 10, 100, $10,000 \mathrm{nM}$ ) in each culture with $S$. costatum and $A$. catenella.

was intended to mimic the natural process when siderophores are released in the environment. This achieved a rather constant iron supply with the apo-siderophore competing against the pool of organic ligands already present. As complexation between DFB and Fe(III) occurs quickly (Hudson et al., 1992), it was then assumed that $\mathrm{Fe}(\mathrm{II})$ oxidized quickly and that the simultaneous addition of apo-siderophore complexed the newly formed $\mathrm{Fe}(\mathrm{III})$. This could be observed in the two highest DFB treatments where the partial DFB additions with a [Fe]:[DFB] ratio of at least 1:250 were able to prevent any significant growth in the diatom cultures for the first 7 days regardless of the $\mathrm{Fe}$ (II) concentration. Yet, this was not the same case observed in the dinoflagellate cultures, which then suggests a biological role in 
the alteration of the Fe speciation. In order to elucidate the main drivers for the growth patterns exhibited in both species, it is important to rule out other possible factors. In this case, detection of the apo-siderophore ( $\mathrm{m} / \mathrm{z}$ value: 561.3616; unpublished data) at $500 \mathrm{nM}$ DFB in a culture medium without algae but with a similar light and addition regime, arguments against the abiotic degradation of the apo-siderophore. Given the presence of the stable FeDFB complex plus that of the apo-form, it could be expected that Fe speciation established at the beginning should have prevented growth throughout the experiment, as observed for the first 7 days at high DFB. Most of the manipulation experiments with siderophores have been conducted with lower concentrations closer to the range that is so far reported for natural waters (Hunter and Boyd, 2007). Given that coastal phytoplankton have been regarded to be less adept at acquiring siderophore bound Fe (Maldonado et al., 2001, 2005; Strzepek et al., 2011), the use of the high DFB gradient (up to $10 \mu \mathrm{M}$ ), also intended to determine the concentration at which the $\mathrm{Fe}$ complexation would render all iron unavailable for uptake in these coastal species.

\section{Skeletonema costatum Response to FeDFB Bound}

Although a ubiquitous species from the coastal environment, available research on the bioavailability of iron for S. costatum is scarce. Previous research conducted on this species (Trick C. et al., 1983), proposed that it could produce siderophores under iron-depleted cultures. Yet, currently no species of eukaryotic phytoplankton has been confirmed to produce siderophores of their own (Hopkinson and Morel, 2009). Skeletonema costatum has been previously studied under the presence of other metal organic binding ligands but not DFB. With the different siderophores used to study $S$. costatum, the diatom has exhibited different degrees of uptake, but none higher than under inorganic Fe (Hutchins D. A. et al., 1999). This constitutes to our knowledge, the first report for a diatom species showing this time delayed response to a siderophore gradient.

The growth pattern observed over time was consistent under the two iron conditions, which minimizes the possibility of experimental bias. It can be further argued that in the treatments above $100 \mathrm{nM}$ DFB, the partial addition every third day (above $20 \mathrm{nM}$ ) of the siderophore was enough to achieve effective complexation of all labile iron available and any TDFe that may have become labile. The delayed growth pattern exhibited by $S$. costatum, particularly at high FeDFB suggests that favorable changes in the Fe speciation occurred over time, allowing the diatom to acquire Fe either directly from the FeDFB complex or previously dissociated. It is argued that natural phytoplankton populations can acquire strongly complexed Fe such as FeDFB only when there is Fe deficiency (Hutchins D. A. et al., 1999; Maldonado and Price, 1999). The most probable mechanism that has been invoked involves Fe reduction, converting the tightly bound FeDFB complex to a loosely bound ferrous complex, which in turn favors its dissociation (Tufano and Raymond, 1981). The $\mathrm{Fe}(\mathrm{II})$ formation measured in diatom cultures from the genus Thalassiosira added FeDFB, provides supporting evidence (Maldonado and Price, 2001). When comparing the same DFB concentrations between 1 and $10 \mathrm{nM} \mathrm{Fe}$, our results suggest an effect of extra Fe(II). The higher growth rate in the Control at $10 \mathrm{nM}$ Fe likely reflects the positive effect of the 10 -fold Fe(II) surplus, whereas the apparently counterintuitive shift to higher growth rates at $1 \mathrm{nM} \mathrm{Fe}$ in all DFB treatments arguably reflects the Fe nutritional status of the diatoms. It is well understood that the up-regulation in the number of cell surface Fe transport systems, as would be the case for Fe-limited cells, could result in considerably faster Fe uptake rates compared to relative Fe-sufficient conditions (Hudson and Morel, 1990). In this case, S. costatum growing at $10 \mathrm{nM}$ Fe was under an overall lower Fe stress across the whole DFB gradient compared to cultures at $1 \mathrm{nM} \mathrm{Fe}$, therefore exhibiting overall lower growth rates.

Despite the difference between 1 and $10 \mathrm{nM} \mathrm{Fe}$, the growth rate at both $\mathrm{Fe}$ (II) concentrations was negatively correlated to the DFB concentration, similar to that described in Maldonado and Price (2001). However, at the highest ratio of DFB to Fe present it was expected that the complexation of Fe would ensure that Fe uptake by the diatom would not be enough to sustain significant growth. Although T. oceanica, is reported to acquire Fe from the FeDFB complex, the diatom exhibited an estimated half-saturation constant for reduction at $0.68 \mu \mathrm{M}$ (Maldonado and Price, 2001), so at such high concentrations (e.g., $10 \mu \mathrm{M}$ ), DFB competes more effectively with the surface transport ligands of the diatom for free Fe' (Nodwell and Price, 2001). Dissociation of FeEDTA due to photoreduction could potentially enhance Fe(II) production (Sunda and Huntsman, 2003), thus over time increasing the Fe pool after reoxidation. If it is assumed that most FeEDTA (40 nM) was dissociated and now bound to DFB, we obtain potential ratios $[\mathrm{Fe}]:[\mathrm{DFB}]$ of $\sim 1: 60$ and $\sim 1: 197$ for 2,500 and 10,000 nM DFB respectively. Although no measurements for the reduction of Fe(III) where performed in this study, according to the reduction half constant estimated for the FeDFB complex, it would not have been enough to sustain growth (Nodwell and Price, 2001), let alone reach the cell densities observed in the 10,000 DFB nM treatment. This raises the question whether the mechanism underlying the late growth exhibited in those treatments is solely reduction or whether other factors such as the associated bacteria may be playing a role. However, this is a question we are not able to answer at present. Furthermore, the time frame employed in the experiment offered the possibility of a different interpretation of the results. By having a prolonged period of monitoring, it allowed to observe the full response from the diatom in all treatments, which would otherwise have been missed with a shorter timeframe. Such observation may aid in reconciling some of the contrasting results between studies that reported very low or negligible growth both in natural community and culture experiments (Wells et al., 1994; Eldridge et al., 2007; Hassler et al., 2011, 2015; Wilhelm et al., 2013).

\section{Alexandrium catenella Response to FeDFB Bound}

Current knowledge of the bioavailability of iron for dinoflagellates is scarce compared to that of diatoms, partly 
because of some significant challenges it presents. Due to the trophic mode and motility in this group, there is a large variety of nutrient uptake modes compared to other major phytoplankton groups. From the motility perspective, dinoflagellates are large motile cells often capable of Diel Vertical Migration (Kamykowski et al., 1998; Smayda, 2010; Peacock and Kudela, 2014), therefore not fulfilling the assumption of motionlessness of the conventional model of $\mathrm{Fe}$ ' dependent uptake (Anderson and Morel, 1982; Völker and Wolf-Gladrow, 1999; Shaked et al., 2005). From the trophic mode perspective, mixotrophy and the difficulty of distinguishing between heterotrophic and autotrophic individuals has been reported as possible bias to account for significantly higher abundances of dinoflagellates observed in culture experiments with DFB (Hutchins D. et al., 1999).

Growth rate values reported for A. catenella under different culture conditions cover a wide range (Navarro et al., 2006; Mardones et al., 2016). With average values ranging from 0.17 to $0.44 \mathrm{~d}^{-1}$, the growth rates estimated in this study fall within the literature range regardless of the siderophore concentration, hence supporting our findings of the limited effect of DFB over A. catenella. For low iron cultures in other dinoflagellate species, maximum growth rates are found from 0.34 to 0.61 $\mathrm{d}^{-1}$ for Gymnodinium sanguineum (Doucette and Harrison, 1990) and Prorocentrum minimum (Sunda and Huntsman, 1995) respectively, both reporting a decrease in growth with decreasing Fe' concentration. These studies approached growth rates in dinoflagellates as if those species were solely autotrophic. However, both G. sanguineum (Bockstahler and Coats, 1993) and P. minimum (Stoecker et al., 1997; Jeong et al., 2005) have thereafter been reported as mixotrophic, feeding on ciliates and bacteria respectively. No mention of use of axenic cultures is made in these studies, making it plausible to explain the decrease in growth without having alternative sources of iron. Furthermore, arguing for siderophore production by P. minimum, Trick C. G. et al. (1983) attributed differences observed in growth rate estimation via In-vivo fluorescence and cell numbers to a drop in fluorescence measured when the described siderophore production was detected. This coincided with the conspicuous drop observed in the FSU in this study. Since it occurred earlier in $1 \mathrm{nM}$ than in $10 \mathrm{nM} \mathrm{Fe}$, it could be seen as a response to iron stress. Also, P. mimimum, showed unusual growth curves where no further growth decrease occurred when reaching certain low Fe'. Sunda and Huntsman (1995) argue that the potential release of siderophores under Fe limitation was the reason for continued growth. As no further evidence of siderophore production in dinoflagellates has been found, it may be possible to argue for mixotrophy as an alternative explanation. A possible shift to ingestion of bacteria would imply metabolic changes that could be represented in the changes in chlorophyll content observed for P. minimum and A. catenella. Likewise, the ingested prey aside from alternative sources of Fe would supply organic carbon as well as essential growth factors, hence explaining the bimodal growth in P. minimum.

Only few studies have tested mixotrophy in red tide dinoflagellates for $\mathrm{Fe}$ acquisition either through strongly complexed colloids or by predation upon bacteria. In an
Fe-deprived culture, Alexandrium tamarense achieved growth after 20 days by adding colloid ferrihydrite at 10 and $50 \mathrm{nM}$ (Wells et al., 1991). With Fe-siderophore complexes and axenic cultures, Heterocapsa circularisquama and Heterocapsa triquetra were not able to grow in a 1:1 [Fe]:[DFB] ratio based culture, whereas Karenia mikimotoi presented slow growth. None of these species grew at 1:10 or 1:100 ratios (Naito et al., 2008). As for bacterial ingestion, it has been previously disputed whether most red tide dinoflagellates are able to feed upon, as bacteria might be too small to be ingested directly (Hansen and Nielsen, 1997; Legrand et al., 1998). For A. catenella, early studies proposed pinocytosis as the only mechanism to ingest high molecular weight particles (Legrand and Carlsson, 1998), but it was recently shown that $A$. catenella is able to ingest bacteria (Jeong et al., 2005). If $A$. catenella would have shifted to prey on bacteria to compensate for the limited iron, the bacterial abundance at high DFB should have reflected this shift. Yet, the opposite results were obtained. If it is assumed that all labile iron was effectively complexed, it can then be argued that A. catenella was able to take up Fe without major constraints on growth different to that seen for S. costatum. Given that the organically bound $\mathrm{Fe}$ is largely membrane impermeable and not directly available for uptake (Hudson and Morel, 1990), it may be possible to assume some mechanism of pinocytosis as for A. catenella (Legrand and Carlsson, 1998) or phagocytosis as for the photosynthetic flagellate Ochromonas sp. (Nodwell and Price, 2001). Nevertheless, final DFe values revealed that a relatively large pool of labile iron remained, hence suggesting possible dissociation of the FeDFB complex over time, perhaps promoted by bacterial mediation.

\section{Bacterial Community in the S. costatum and $A$. catenella Cultures}

Bacteria closely associated with phytoplankton are believed to be involved in a wide range of mutualistic interactions. From nutrient provision and remineralization (Croft et al., 2005; Cruz-López and Maske, 2016), inhibition or promotion of cyst formation (Bolch et al., 2011), algicidal or bacterioprotective effects (Mayali and Doucette, 2002; Mayali et al., 2008), to the production of paralytic shellfish toxin (Hold et al., 2001; Uribe and Espejo, 2003; Green et al., 2004). Currently, several of these interactions are still poorly understood (Amin et al., 2012). Moreover, all of these interactions have not only ecological relevance but may play a key role in biogeochemical cycling. Arguably one of the most relevant interactions is the mutualistic uptake of nutrients such as iron and carbon (Kirchman et al., 2000; Jasti et al., 2005; Amin et al., 2009).

The relationship exhibited between the algae and the bacteria present in this study highlights the differences in the composition of bacterial communities associated to different phytoplankton species and functional groups. Although initial bacterial densities in both $S$. costatum and A. catenella cultures were similar, we observed different trends over time in the response to the siderophore concentration. Proteobacteria and Bacteroidetes are the main gram-negative heterotrophic bacterial phyla associated with diatoms, of which Sulfitobacter, Roseobacter, Alteromonas, 
and Flavobacterium appeared to be strongly associated genera (Amin et al., 2012 and cites therein). While most gram-negative bacteria are able to utilize FeDFB (Granger and Price, 1999), the results suggests that the presence of the FeDFB complex presented no advantage for the bacterial community associated to S. costatum. The overall lower bacterial abundance in treatments compared to that in Controls suggests that Fe uptake was also constrained or that another factor became limiting. Dissolved organic carbon (DOC) and organic matter, generally produced by the diatom, may be a probable cause. If the associated bacteria were significantly dependent on increased DOC, consequently both bacteria and diatom populations would have followed a similar growth pattern.

It is presumed that bacteria present in the dinoflagellate cultures were also to some extent influenced by the availability of DOC. This could be seen in the Controls of $A$. catenella cultures that had a carbon biomass $\sim 50 \%$ of that reached in S. costatum Controls. On the other hand, the contrasting growth proportional to DFB concentration, suggests that the presence of the FeDFB complex conferred an advantage to the bacterial community associated with $A$. catenella, hence enhancing its growth over that in the Control. If mixotrophy did not play a role in alleviating any possible $\mathrm{Fe}$ stress in A. catenella by effective ingestion of bacteria, it could be speculated that in turn enhanced growth of bacteria may be playing a positive role for the dinoflagellate. Such evidence exists through the photoreduction of $\alpha$-hydroxycarboxylate type siderophore complexes. In natural waters and laboratory cultures, changes in photoactive siderophore production by bacteria during and after a bloom of the dinoflagellate Lingulodinium polyedrum (Yarimizu et al., 2014); or static growth of bacteria associated to Scrippsiella trochoidea in the absence of the dinoflagellate (Amin et al., 2009), highlight the mutualistic interaction in which the increase in bacteria provides a source of bioavailable iron. This type of interaction may have further implications as it could be involved in dinoflagellate bloom initiation as for Marinobacter sp. and L. polyedrum (Yarimizu et al., 2014), or Roseobacter, frequently associated with toxic dinoflagellates Alexandrium spp. (Jasti et al., 2005). By having in an experiment the full spectrum of the associated bacterial community, being complex and diverse, can cause direct, indirect, and potentially confounding interactions with the algae and among the bacteria (Bolch et al., 2011). Nonetheless, it may also contribute to the elucidation of the complex interactions between phytoplankton and bacteria that otherwise would not be possible by having axenic algal cultures.

\section{CONCLUSIONS}

The interaction between the simultaneous additions of $\mathrm{Fe}(\mathrm{II})$ and the apo-siderophore desferrioxamine $\mathrm{B}$ in cultures with

\section{REFERENCES}

Albrecht-Gary, A., Crumbliss, A., Sigel, A., and Sigel, H. (1998). Metal Ions in Biological Systems, Vol. 35, eds A. Sigel and H. Sigel (New York, NY: Marcel Dekker).
S. costatum and A. catenella showed a more significant effect for the diatom in terms of the impact in the overall physiology. The growth patterns exhibited over time in the diatom and the dinoflagellate differed greatly with respect to the effect of the siderophore concentration. In the former, it was negatively correlated to the DFB and only alleviated over time. In the latter, it was from moderately enhanced under low DFB to an overall attenuated negative effect at high DFB. Remarkably, the bacteria associated with each of these species presented contrasting abundance trends over time, in a certain way mimicking the trend of the corresponding diatom and dinoflagellate. Despite not being able to address the driver behind the patterns observed in both bacteria and phytoplankton species involved, it highlights the role of mutualistic interactions for nutrient acquisition, in this case the possible alleviation of induced Fe stress.

The concentration gradient of the siderophore DFB over time, allowed for the evaluation of the different uptake strategies between species of two different dominant groups of phytoplankton. Likewise, it highlights the relevance of studying the interactions of the autochthonous bacterial communities and the different phytoplankton species and their roles in the bioavailability of iron.

\section{AUTHOR CONTRIBUTIONS}

Experimental design conceived by MA, YO, JI, HG and NS. EB and NS carried out the main experimental part and analysis, with contributions of JI and HG. OV contributed to part of the analysis. Writing was performed mainly by NS with comments and discussion of the results with all others authors.

\section{FUNDING}

This work was supported by the Department of Chemistry, Faculty of Natural Sciences, Norwegian University of Science and Technology (NTNU). Additional support also provided by the project: A Cross-disciplinary Integrated Eco-system Eutrophication Research and Management ApproachCINTERA (project no.: 216607), funded the Research Council of Norway and by the EU project: Ocean Food-web Patrol-Climate Effects: Reducing Targeted Uncertainties with an Interactive Network. European Commission (OCEAN-CERTAIN, FP7-ENV-2013-6.1-1: no.: 603773).

\section{ACKNOWLEDGMENTS}

Thanks to the people at the ICML at the Universidad Austral and at the Trondheim Biological Station at NTNU for the assistance provided during the experimental phases.
Amin, S. A., Green, D. H., Hart, M. C., Küpper, F. C., Sunda, W. G., and Carrano, C. J. (2009). Photolysis of ironsiderophore chelates promotes bacterial-algal mutualism. Proc. Natl. Acad. Sci. U.S.A. 106, 17071-17076. doi: 10.1073/pnas.09055 12106 
Amin, S. A., Parker, M. S., and Armbrust, E. V. (2012). Interactions between diatoms and bacteria. Microbiol. Mol. Biol. Rev. 76, 667-684. doi: 10.1128/MMBR.00007-12

Anderson, M. A., and Morel, F. M. M. (1982). The influence of aqueous iron chemistry on the uptake of iron by the coastal diatom Thalassiosira weissflogii. Limnol. Oceanogr. 27, 789-813. doi: 10.4319/lo.1982.27.5.0789

Ardelan, M., Holm-Hansen, O., Hewes, C., Reiss, C. S., Silva, N., Dulaiova, H., et al. (2010). Natural iron enrichment around the Antarctic Peninsula in the Southern Ocean. Biogeosciences 7, 11-25. doi: 10.5194/bg-7-11-2010

Barbeau, K., Rue, E. L., Trick, C. G., Bruland, K. W., and Butler, A. (2003). Photochemical reactivity of siderophores produced by marine heterotrophic bacteria and cyanobacteria based on characteristic Fe (III) binding groups. Limnol. Oceanogr. 48, 1069-1078. doi: 10.4319/lo.2003.48.3.1069

Bockstahler, K., and Coats, D. (1993). Grazing of the mixotrophic dinoflagellate Gymnodinium sanguineum on ciliate populations of Chesapeake Bay. Mar. Biol. 116, 477-487. doi: 10.1007/BF00350065

Boiteau, R. M., Mende, D. R., Hawco, N. J., Mcilvin, M. R., Fitzsimmons, J. N., Saito, M. A., et al. (2016). Siderophore-based microbial adaptations to iron scarcity across the eastern Pacific Ocean. Proc. Natl. Acad. Sci. U.S.A. 113, 14237-14242. doi: 10.1073/pnas.1608594113

Bolch, C. J., Subramanian, T. A., and Green, D. H. (2011). The toxic dinoflagellate gymnodinium catenatum (dinophyceae) requires marine bacteria for growth. J. Phycol. 47, 1009-1022. doi: 10.1111/j.1529-8817.2011.01043.x

Boukhalfa, H., and Crumbliss, A. L. (2002). Chemical aspects of siderophore mediated iron transport. Biometals 15, 325-339. doi: 10.1023/A:1020218608266

Bruland, K. W., Rue, E. L., and Smith, G. J. (2001). Iron and macronutrients in California coastal upwelling regimes: implications for diatom blooms. Limnol. Oceanogr. 46, 1661-1674. doi: 10.4319/lo.2001.46.7.1661

Butler, A. (2005). Marine siderophores and microbial iron mobilization. Biometals 18, 369-374. doi: 10.1007/s10534-005-3711-0

Croft, M. T., Lawrence, A. D., Raux-Deery, E., Warren, M. J., and Smith, A. G. (2005). Algae acquire vitamin B12 through a symbiotic relationship with bacteria. Nature 438, 90-93. doi: 10.1038/nature04056

Cruz-López, R., and Maske, H. (2016). The Vitamin B1 and B12 Required by the Marine Dinoflagellate Lingulodinium polyedrum Can be Provided by its Associated Bacterial Community in Culture. Front. Microbiol. 7:560. doi: $10.3389 /$ fmicb. 2016.00560

De Baar, H. J. (1990). On iron limitation of the Southern Ocean: experimental observations in the Weddell and Scotia Seas. Marine Ecol. Prog. Ser. 65, 105-122. doi: 10.3354/meps065105

Doucette, G. J., and Harrison, P. J. (1990). Some effects of iron and nitrogen stress on the red tide dinoflagellate Gymnodinium sanguineum. Marine ecology progress series. Oldendorf 62, 293-306. doi: 10.3354/meps062293

Doucette, G., and Harrison, P. (1991). Aspects of iron and nitrogen nutrition in the red tide dinoflagellate Gymnodinium sanguineum. Mar. Biol. 110, 165-173. doi: 10.1007/BF01313701

Eldridge, M. L., Cadotte, M. W., Rozmus, A. E., and Wilhelm, S. W. (2007). The response of bacterial groups to changes in available iron in the Eastern subtropical Pacific Ocean. J. Exp. Mar. Biol. Ecol. 348, 11-22. doi: 10.1016/j.jembe.2007.02.018

Finden, D., Tipping, E., Jaworski, G., and Reynolds, C. (1984). Light-induced reduction of natural iron (III) oxide and its relevance to phytoplankton. Nature 309, 783-784. doi: 10.1038/309783a0

Gledhill, M., and Buck, K. N. (2012). The organic complexation of iron in the marine environment: a review. Front. Microbiol. 3:69. doi: $10.3389 /$ fmicb. 2012.00069

Gledhill, M., Mccormack, P., Ussher, S., Achterberg, E. P., Mantoura, R. F. C., and Worsfold, P. J. (2004). Production of siderophore type chelates by mixed bacterioplankton populations in nutrient enriched seawater incubations. Mar. Chem. 88, 75-83. doi: 10.1016/j.marchem.2004.03.003

Glover, H. E. (1978). Iron in Maine coastal waters; seasonal variation and its apparent correlation with a dinoflagellate bloom. Limnol. Oceanogr. 23, 534-537. doi: 10.4319/lo.1978.23.3.0534

Granger, J., and Price, N. M. (1999). The importance of siderophores in iron nutrition of heterotrophic marine bacteria. Limnol. Oceanogr. 44, 541-555. doi: 10.4319/lo.1999.44.3.0541

Green, D. H., Llewellyn, L. E., Negri, A. P., Blackburn, S. I., and Bolch, C. J. (2004). Phylogenetic and functional diversity of the cultivable bacterial community associated with the paralytic shellfish poisoning dinoflagellate Gymnodinium catenatum. FEMS Microbiol. Ecol. 47, 345-357. doi: 10.1016/S0168-6496(03)00298-8

Guillard, R. R. (1973). Division rates. Handb. Phycol. Methods 1, 289-312.

Guillard, R. R., and Ryther, J. H. (1962). Studies of marine planktonic diatoms: I. Cyclotella Nana Hustedt, and Detonula Confervacea (CLEVE) Gran. Can. J. Microbiol. 8, 229-239. doi: 10.1139/m62-029

Guillard, R., and Hargraves, P. (1993). Stichochrysis immobilis is a diatom, not a chrysophyte. Phycologia 32, 234-236. doi: 10.2216/i0031-8884-32-3-234.1

Hansen, P. J., and Nielsen, T. (1997). Mixotrophic feeding of Fragilidium subglobosum (Dinophyceae) on three species of Ceratium: effects of prey concentration, prey species and light intensity. Mar. Ecol. Prog. Ser. 147, 187-196. doi: 10.3354/meps 147187

Hassler, C. S., Norman, L., Mancuso Nichols, C. A., Clementson, L. A., Robinson, C., Schoemann, V., et al. (2015). Iron associated with exopolymeric substances is highly bioavailable to oceanic phytoplankton. Mar. Chem. 173, 136-147. doi: 10.1016/j.marchem.2014.10.002

Hassler, C. S., Schoemann, V., Nichols, C. M., Butler, E. C., and Boyd, P. W. (2011). Saccharides enhance iron bioavailability to Southern Ocean phytoplankton. Proc. Natl. Acad. Science. U.S.A. 108, 1076-1081. doi: 10.1073/pnas.1010963108

Hassler, C., and Schoemann, V. (2009). Bioavailability of organically bound Fe to model phytoplankton of the Southern Ocean. Biogeosciences 6, 2281-2296. doi: 10.5194/bg-6-2281-2009

Hold, G. L., Smith, E. A., Birkbeck, T. H., and Gallacher, S. (2001). Comparison of paralytic shellfish toxin (PST) production by the dinoflagellates Alexandrium lusitanicum NEPCC 253 and Alexandrium tamarense NEPCC 407 in the presence and absence of bacteria. FEMS Microbiol. Ecol. 36, 223-234. doi: 10.1111/j.1574-6941.2001.tb00843.x

Hopkinson, B. M., and Morel, F. M. (2009). The role of siderophores in iron acquisition by photosynthetic marine microorganisms. Biometals 22, 659-669. doi: 10.1007/s10534-009-9235-2

Hudson, R. J., and Morel, F. M. (1990). Iron transport in marine phytoplankton: kinetics of cellular and medium coordination reactions. Limnol. Oceanogr. 1002-1020. doi: 10.4319/lo.1990.35.5.1002

Hudson, R. J., Covault, D. T., and Morel, F. M. (1992). Investigations of iron coordination and redox reactions in seawater using 59Fe radiometry and ionpair solvent extraction of amphiphilic iron complexes. Mar. Chem. 38, 209-235. doi: 10.1016/0304-4203(92)90035-9

Hunter, K. A., and Boyd, P. W. (2007). Iron-binding ligands and their role in the ocean biogeochemistry of iron. Environ. Chem. 4:221. doi: 10.1071/EN07012

Hutchins, D. A., Witter, A. E., Butler, A., and Luther, G. W. (1999). Competition among marine phytoplankton for different chelated iron species. Nature 400, 858-861. doi: $10.1038 / 23680$

Hutchins, D., Ditullio, G., Zhang, Y., and Bruland, K. (1998). An iron limitation mosaic in the California upwelling regime. Limnol. Oceanogr. 43, 1037-1054. doi: 10.4319/lo.1998.43.6.1037

Hutchins, D., Franck, V., Brzezinski, M., and Bruland, K. (1999). Inducing phytoplankton iron limitation in iron-replete coastal waters with a strong chelating ligand. Limnol. Oceanogr. 44, 1009-1018. doi: 10.4319/lo.1999.44.4.1009

Ingle, R. M., and Martin, D. F. (1971). Prediction of the Florida red tide by means of the iron index: red tide, iron and humic acid levels in streams. Environ. Lett. 1, 69-74. doi: 10.1080/00139307109434970

Jasti, S., Sieracki, M. E., Poulton, N. J., Giewat, M. W., and Rooney-Varga, J. N. (2005). Phylogenetic diversity and specificity of bacteria closely associated with Alexandrium spp. and other phytoplankton. Appl. Environ. Microbiol. 71, 3483-3494. doi: 10.1128/AEM.71.7.3483-3494.2005

Jeong, H. J., Du Yoo, Y., Kim, J. S., Seong, K. A., Kang, N. S., and Kim, T. H. (2010). Growth, feeding and ecological roles of the mixotrophic and heterotrophic dinoflagellates in marine planktonic food webs. Ocean Sci. J. 45, 65-91. doi: 10.1007/s12601-010-0007-2

Jeong, H. J., Park, J. Y., Nho, J. H., Park, M. O., Ha, J. H., Seong, K. A., et al. (2005). Feeding by red-tide dinoflagellates on the cyanobacterium Synechococcus. Aquat. Microbial. Ecol. 41, 131-143. doi: 10.3354/ame041131

Jeong, H. J., Song, J. E., Kang, N. S., Kim, S., Du Yoo, Y., and Park, J. Y. (2007). Feeding by heterotrophic dinoflagellates on the common marine heterotrophic nanoflagellate Cafeteria sp. Mar. Ecol. Prog. Ser. 333, 151-160. doi: $10.3354 /$ meps333151 
Johnson, K. S., Gordon, R. M., and Coale, K. H. (1997). What controls dissolved iron concentrations in the world ocean? Mar. Chem. 57, 137-161. doi: 10.1016/S0304-4203(97)00043-1

Kamykowski, D., Milligan, E., and Reed, R. (1998). Relationships between geotaxis/phototaxis and diel vertical migration in autotrophic dinoflagellates. J. Plankton Res. 20, 1781-1796. doi: 10.1093/plankt/20.9.1781

Kirchman, D. L., Meon, B., Cottrell, M. T., Hutchins, D. A., Weeks, D., and Bruland, K. W. (2000). Carbon versus iron limitation of bacterial growth in the California upwelling regime. Limnol. Oceanogr. 45, 1681-1688. doi: 10.4319/lo.2000.45.8.1681

Kustka, A. B., Jones, B. M., Hatta, M., Field, M. P., and Milligan, A. J. (2015). The influence of iron and siderophores on eukaryotic phytoplankton growth rates and community composition in the Ross Sea. Mar. Chem. 173, 195-207. doi: 10.1016/j.marchem.2014.12.002

Legrand, C., and Carlsson, P. (1998). Uptake of high molecular weight dextran by the dinoflagellate Alexandrium catenella. Aquat. Microbial. Ecol. 16, 81-86. doi: 10.3354/ame016081

Legrand, C., Graneli, E., and Carlsson, P. (1998). Induced phagotrophy in the photosynthetic dinoflagellate Heterocapsa triquetra. Aquat. Microbial. Ecol. 15, 65-75. doi: 10.3354/ame015065

Macrellis, H. M., Trick, C. G., Rue, E. L., Smith, G., and Bruland, K. W. (2001). Collection and detection of natural iron-binding ligands from seawater. Mar. Chem. 76, 175-187. doi: 10.1016/S0304-4203(01)00061-5

Maldonado, M. T., and Price, N. M. (1999). Utilization of iron bound to strong organic ligands by plankton communities in the subarctic Pacific Ocean. Deep Sea Res. II Top. Stud. Oceanogr. 46, 2447-2473. doi: 10.1016/S0967-0645(99)00071-5

Maldonado, M. T., and Price, N. M. (2001). Reduction and transport of organically bound iron by Thalassiosira oceanica (Bacillariophyceae). J. Phycol. 37, 298-310. doi: 10.1046/j.1529-8817.2001.037002298.x

Maldonado, M. T., Boyd, P. W., Laroche, J., Strzepek, R., Waite, A., Bowie, A. R., et al. (2001). Iron uptake and physiological response of phytoplankton during a mesoscale Southern Ocean iron enrichment. Limnol. Oceanogr. 46, 1802-1808. doi: $10.4319 /$ lo.2001.46.7.1802

Maldonado, M. T., Strzepek, R. F., Sander, S., and Boyd, P. W. (2005). Acquisition of iron bound to strong organic complexes, with different $\mathrm{Fe}$ binding groups and photochemical reactivities, by plankton communities in Fe-limited subantarctic waters. Global Biogeochem. Cycles 19:GB4S23. doi: 10.1029/2005GB002481

Mardones, J. I., Bolch, C., Guzmán, L., Paredes, J., Varela, D., and Hallegraeff, G. M. (2016). Role of resting cysts in Chilean Alexandrium catenella dinoflagellate blooms revisited. Harmful Algae 55, 238-249. doi: 10.1016/j.hal.2016.03.020

Marie, D., Partensky, F., Jacquet, S., and Vaulot, D. (1997). Enumeration and cell cycle analysis of natural populations of marine picoplankton by flow cytometry using the nucleic acid stain SYBR Green I. Appl. Environ. Microbiol. $63,186-193$.

Martin, J. H., and Gordon, M. R. (1988). Northeast Pacific iron distributions in relation to phytoplankton productivity. Deep Sea Res. A. Oceanogr. Res. Papers 35, 177-196. doi: 10.1016/0198-0149(88)90035-0

Mawji, E., Gledhill, M., Milton, J. A., Tarran, G. A., Ussher, S., Thompson, A., et al. (2008). Hydroxamate siderophores: occurrence and importance in the Atlantic Ocean. Environ. Sci. Technol. 42, 8675-8680. doi: 10.1021/es801884r

Mayali, X., and Doucette, G. J. (2002). Microbial community interactions and population dynamics of an algicidal bacterium active against Karenia brevis (Dinophyceae). Harmful Algae 1, 277-293. doi: 10.1016/S1568-9883(02)00032-X

Mayali, X., Franks, P. J., Tanaka, Y., and Azam, F. (2008). Bacteria-induced motility reduction in lingulodinium polyedrum (Dinophyceae) 1. J. Phycol. 44, 923-928. doi: $10.1111 / j .1529-8817.2008 .00549 . x$

McCormack, P., Worsfold, P. J., and Gledhill, M. (2003). Separation and detection of siderophores produced by marine bacterioplankton using high-performance liquid chromatography with electrospray ionization mass spectrometry. Anal. Chem. 75, 2647-2652. doi: 10.1021/ac0340105

Morel, F. M., Rueter, J., Anderson, D. M., and Guillard, R. (1979). Aquil: a chemically defined phytoplankton culture medium for trace metal Studies12. J. Phycol. 15, 135-141. doi: 10.1111/j.0022-3646.1979.00135.x

Naito, K., Imai, I., and Nakahara, H. (2008). Complexation of iron by microbial siderophores and effects of iron chelates on the growth of marine microalgae causing red tides. Phycol. Res. 56, 58-67. doi: 10.1111/j.1440-1835.2008.00485.x
Navarro, J., Munoz, M., and Contreras, A. (2006). Temperature as a factor regulating growth and toxin content in the dinoflagellate Alexandrium catenella. Harmful Algae 5, 762-769. doi: 10.1016/j.hal.2006.04.001

Nodwell, L. M., and Price, N. M. (2001). Direct use of inorganic colloidal iron by marine mixotrophic phytoplankton. Limnol. Oceanogr. 46, 765-777. doi: 10.4319/lo.2001.46.4.0765

Öztürk, M., and Bizsel, N. (2003). Iron speciation and biogeochemistry in different nearshore waters. Mar. Chem. 83, 145-156. doi: 10.1016/S0304-4203(03)00108-7

Öztürk, M., Steinnes, E., and Sakshaug, E. (2002). Iron speciation in the trondheim fjord from the perspective of iron limitation for phytoplankton. Estuar. Coast. Shelf Sci. 55, 197-212. doi: 10.1006/ecss.2001.0897

Peacock, M. B., and Kudela, R. M. (2014). Evidence for active vertical migration by two dinoflagellates experiencing iron, nitrogen, and phosphorus limitation. Limnol. Oceanogr. 59, 660-673. doi: 10.4319/lo.2014.59.3.0660

Price, N. M., Harrison, G. I., Hering, J. G., Hudson, R. J., Nirel, P. M., Palenik, B., et al. (1989). Preparation and chemistry of the artificial algal culture medium Aquil. Biol. Oceanogr. 6, 443-461.

Raven, J. A. (1988). The iron and molybdenum use efficiencies of plant growth with different energy, carbon and nitrogen sources. New Phytol. 109, 279-287. doi: 10.1111/j.1469-8137.1988.tb04196.x

Rue, E. L., and Bruland, K. W. (1995). Complexation of iron (III) by natural organic ligands in the Central North Pacific as determined by a new competitive ligand equilibration/adsorptive cathodic stripping voltammetric method. Mar. Chem. 50, 117-138. doi: 10.1016/0304-4203(95)00031-L

Shaked, Y., and Lis, H. (2012). Disassembling iron availability to phytoplankton. Front. Microbiol. 3:123. doi: 10.3389/fmicb.2012.00123

Shaked, Y., Kustka, A. B., and Morel, F. M. (2005). A general kinetic model for iron acquisition by eukaryotic phytoplankton. Limnol. Oceanogr. 50, 872-882. doi: 10.4319/lo.2005.50.3.0872

Smayda, T. (2010). Adaptations and selection of harmful and other dinoflagellate species in upwelling systems. 2. Motility and migratory behaviour. Progr. Oceanogr. 85, 71-91. doi: 10.1016/j.pocean.2010.02.005

Soria-Dengg, S., and Horstmann, U. (1995). Ferrioxamines B and E as iron sources for the marine diatom Phaeodactylum tricornutum. Mar. Ecol. Prog. Ser. 127, 269-277. doi: 10.3354/meps127269

Soria-Dengg, S., Reissbrodt, R., and Horstmann, U. (2001). Siderophores in marine coastal waters and their relevance for iron uptake by phytoplankton: experiments with the diatom Phaeodactylum tricornutum. Mar. Ecol. Prog. Ser. 220, 73-82. doi: 10.3354/meps220073

Stoecker, D., Li, A., Coats, D. W., Gustafson, D., and Nannen, M. (1997). Mixotrophy in the dinoflagellate Prorocentrum minimum. Mar. Ecol. Prog. Ser. 152, 1-12. doi: 10.3354/meps152001

Strzepek, R. F., Maldonado, M. T., Hunter, K. A., Frew, R. D., and Boyd, P. W. (2011). Adaptive strategies by Southern Ocean phytoplankton to lessen iron limitation: uptake of organically complexed iron and reduced cellular iron requirements. Limnol. Oceanogr. 56, 1983-2002. doi: 10.4319/lo.2011.56.6.1983

Sunda and Huntsman, S. A. (1995). Iron uptake and growth limitation in oceanic and coastal phytoplankton. Mar. Chem. 50, 189-206. doi: 10.1016/0304-4203(95)00035-P

Sunda, W. G. (2001). "Bioavailability and bioaccumulation of iron in the sea," in The biogeochemistry of iron in seawater, IUPAC Series on Analytical and Physical Chemistry of Environmental Systems, Vol. 7 (Chichester: Wiley), 41-84.

Sunda, W., and Huntsman, S. (2003). Effect of pH, light, and temperature on Fe-EDTA chelation and Fe hydrolysis in seawater. Mar. Chem. 84, 35-47. doi: 10.1016/S0304-4203(03)00101-4

Tang, E. P. (1996). Why do dinoflagellates have lower growth rates? 1. J. Phycol. 32, 80-84. doi: 10.1111/j.0022-3646.1996.00080.x

Trick, C. G., Andersen, R. J., Gillam, A., and Harrison, P. J. (1983). Prorocentrin: an extracellular siderophore produced by the marine dinoflagellate Prorocentrum minimum. Science 219, 306-308. doi: 10.1126/science.219.4582.306

Trick, C., Andersen, R., Price, N., Gillam, A., and Harrison, P. (1983). Examination of hydroxamate-siderophore production by neritic eukaryotic marine phytoplankton. Mar. Biol. 75, 9-17. doi: 10.1007/BF00392625

Tufano, T. P., and Raymond, K. N. (1981). Coordination chemistry of microbial iron transport compounds. 21. Kinetics and mechanism of iron exchange in hydroxamate siderophore complexes. J. Am. Chem. Soc. 103, 6617-6624. doi: 10.1021/ja00412a015 
Uribe, P., and Espejo, R. T. (2003). Effect of associated bacteria on the growth and toxicity of Alexandrium catenella. Appl. Environ. Microbiol. 69, 659-662. doi: 10.1128/AEM.69.1.659-662.2003

Van Den Berg, C. M. (1995). Evidence for organic complexation of iron in seawater. Mar. Chem. 50, 139-157. doi: 10.1016/0304-4203(95)00032-M

Velasquez, I., Nunn, B. L., Ibisanmi, E., Goodlett, D. R., Hunter, K. A., and Sander, S. G. (2011). Detection of hydroxamate siderophores in coastal and Sub-Antarctic waters off the South Eastern Coast of New Zealand. Mar. Chem. 126, 97-107. doi: 10.1016/j.marchem.2011.04.003

Völker, C., and Wolf-Gladrow, D. A. (1999). Physical limits on iron uptake mediated by siderophores or surface reductases. Mar. Chem. 65, 227-244. doi: 10.1016/S0304-4203(99)00004-3

Wells, M. L. (1999). Manipulating iron availability in nearshore waters. Limnol. Oceanogr. 44, 1002-1008. doi: 10.4319/lo.1999.44.4.1002

Wells, M. L., Price, N. M., and Bruland, K. W. (1994). Iron limitation and the cyanobacterium Synechococcus in equatorial Pacific waters. Limnol. Oceanogr. 39, 1481-1486. doi: 10.4319/lo.1994.39.6.1481

Wells, M., Mayer, L., and Guillard, R. (1991). Evaluation of iron as a triggering factor for red tide blooms. Marine Ecol. Progr. Ser. 69, 93-102. doi: $10.3354 /$ meps069093
Wilhelm, S. W., King, A. L., Twining, B. S., Lecleir, G. R., Debruyn, J. M., Strzepek, R. F., et al. (2013). Elemental quotas and physiology of a southwestern Pacific Ocean plankton community as a function of iron availability. Aquat. Microbial. Ecol. 68, 185-194. doi: 10.3354/ame01611

Yarimizu, K., Polido, G., Gärdes, A., Carter, M. L., Hilbern, M., and Carrano, C. J. (2014). Evaluation of photo-reactive siderophore producing bacteria before, during and after a bloom of the dinoflagellate Lingulodinium polyedrum. Metallomics 6, 1156-1163. doi: 10.1039/C4MT00053F

Conflict of Interest Statement: The authors declare that the research was conducted in the absence of any commercial or financial relationships that could be construed as a potential conflict of interest.

Copyright (C) 2018 Sanchez, Brown, Olsen, Vadstein, Iriarte, Gonzalez and Ardelan. This is an open-access article distributed under the terms of the Creative Commons Attribution License (CC BY). The use, distribution or reproduction in other forums is permitted, provided the original author(s) and the copyright owner are credited and that the original publication in this journal is cited, in accordance with accepted academic practice. No use, distribution or reproduction is permitted which does not comply with these terms. 